\title{
Adaptation and Growth Performance of Multipurpose Tree Species under Erer Dodota condition, Harari Region, Ethiopia
}

\author{
Musa Abdella* and Bira Cheneke \\ Fedis Agricultural Research Center, Ethiopia
}

Submission: March 18, 2020; Published: April 06, 2020

*Corresponding author: Musa Abdella, Fedis Agricultural Research Center, Harar, P.O. Box 904, Ethiopia

\section{Abstract}

A study was conducted to evaluate adaptation and growth performance of five multipurpose tree species at Erer Dodota Kebele, Harari Regional State for three years (June 2016 - June 2019). Five multipurpose tree species (Sesbania sesban, Moringa oliefera, Gravilea robusta, Azadarichta indica and Leuceana leucocephala) were compared in randomized complete block design with three replications. Data on growth parameters, diameter, and plant height and survival rate were measured and recorded at interval of three months. Results revealed that there were highly significant $(\mathrm{p}<0.05)$ variations among tree species in height growth, root collar diameter development, diameter at breast height and survival rate at the study area. Among the species tasted, Moringa oliefera showed the highest performance followed by Azadarichta indica, Sesbania sesban and Leuceana leucocephala in terms of height growth, root collar diameter and diameter at breast height at Erer Dodota Kebele. After three years of establishment, Moringa oliefera, Azadarichta indica, Sesbania sesban and Leuceana leucocephala showed the highest mean survival rate at the study area. Hence it can be inferred that the conditions of Erer Dodota matched with the environmental requirement of those tree species. On the other hand, species of Gravilea robusta showed lowest performance at the study area. Thus, the long dry season, which extended from eight to ten months in the study area, clearly explains the poor survival and growth response in some of the species. Generally, the study under Erer Dodota condition and related agro ecology, we advocate these adapted species and properly allocate species into the site that grow and adapt well for further agroforestry practices at wider scale on which success of agroforestry practices and forest plantations depend.

Keywords: Erer Dodota; Multipurpose tree; Height growth, Survival rate

\section{Introduction}

Eastern Ethiopian high land is well known by vegetation cover and most of the surrounding area is covered by forests comprised of a rich mixture of woody species [1]. In spite of the importance of forest ecosystem to the livelihoods of the people in the area, the forest is dwindling from time to time due to high exploitation of woody and non-woody products. Rapid deforestation caused by an escalating demand for fuel wood expansion for agriculture has brought an ever-increasing pressure on native woodland species [2]. If no remedial action is taken, this will cause severe impact on agricultural productivity leading to energy poverty and environmental degradation. Frequent and severe droughts often present a serious threat for millions of lives [3], which have occurred once in a decade in the 1970s and 1980s. Shortages of animal feed and biomass energy are also such an unsustainable use of natural resources. Currently, biomass energy constitutes 88.7\% of all energy consumed in Ethiopia which is mainly derived from the woody biomass resources (forests, woodlands, shrub lands, planted trees, agro forests). Agro forestry system has much potential for supplying fodder, poles, farm equipment, fuel wood and agricultural improvements [1].

Multipurpose tree and shrubs species (MPTS) play a considerable role in addressing such multifaceted demands in the mixed crop-livestock production system [4]. They have the ability to fit into the farming system to be used as a source of manure, mulch, soil conservation, forage, fuelwood, farm implements and other like shade and shelter [5]. In Erer Waldaya district, farmers practice on farm and homegarden for economic, social and environmental benefits [6]. These traditional agroforestry practices could be intensified by using fast growing multipurpose tree species (MPTS) to satisfy the demands of the growing population. Thus, before introducing any species to a given agro ecology, there is always a need for a well conducted field trial for matching of the species/provenance to a particular site [2]. The species screening trial that will test the survival and early growth 
of the species in one to three years. Deciding what species to plant in any agroforestry system to meet the intended objectives require a well- conducted field trial to match a species to a particular site.

Many species screening experiments have been conducted in different parts of country [4]. However information is scarce at Erer Waldaya district, to recommend promising multipurpose tree and shrubs species for use in agroforestry practices. Hence, there is a need to investigate adaptable and promising tree and shrubs species in the area. Therefore this trail was designed to evaluate the adaptation and growth performance of five multipurpose tree species to Erer Dodota conditions and sites of similar agroecology.

\section{Materials and Methods}

\section{Description of the study area}

The study was conducted at Harari Region, Erer Waldea District on Farmers Training Center (FTC) which is located in eastern of Ethiopia. It is found at $530 \mathrm{~km}$ away from Finfinne, $20 \mathrm{~km}$ from the nearby Harar town. The elevation of the District is $1300-1800$ m.a.s.l, temperature $24-34^{\circ} \mathrm{c}$, rainfall $1000-1200 \mathrm{~mm}$ which has a bimodal type of rainfall and beautiful scene for vision and is quite conducive for agricultural production system under rain-fed in the present climatic conditions (Figure $1 \& 2$ ).

Figure 1: Map of the study area.
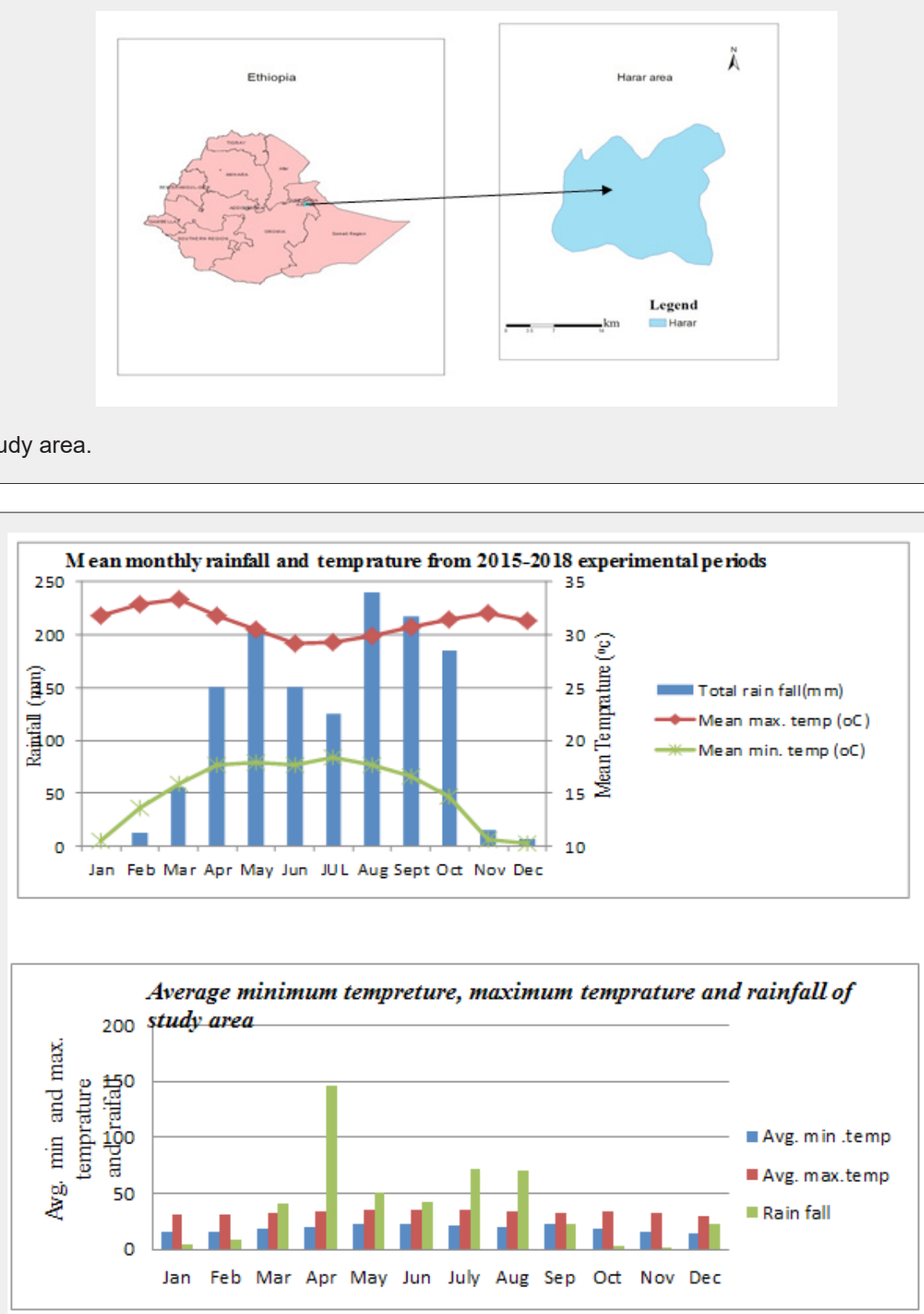

Figure 2: Mean monthly rainfall and temperature during experimental period at Harari Region based on meteorological data nearest to the study area. 


\section{Seeds source}

Seeds of five agroforestry tree species were obtained from Central Ethiopian Environment and Forestry Research Center (Table 1).

Table 1: Details of tree species used in the adaptation trial.

\begin{tabular}{|c|c|c|}
\hline Tree Species & Family Name & Seeds Source \\
\hline Sesbania sesban & Leguminosae & CEFRC \\
\hline Leuceana leucocephala & Leguminosae & CEFRC \\
\hline Moringa oliefera & Moringaceae & CEFRC \\
\hline Azadarichta indica & Meliaceae & CEFRC \\
\hline Gravilea robusta & Proteaceae & CEFRC \\
\hline
\end{tabular}

CEEFRC: Central Ethiopian Environment and Forestry Research Center.

\section{Treatments and experimental design}

Seedlings of tree species (Sesbania sesban, Gravilea robusta, Azadarichta indica, Leuceana leucocephala and Moringa oliefera) were raised directly into polythene tubes at Erer nursery sites with the recommendation of nursery activities. Seedlings with the same age of these tree species were planted in the field in June, 2016 at experimental sites using a randomized complete block design with three replications. Each replication had five experimental plots, representing five tree species of nine seedlings each. The spacing between blocks and plots were $2.5 \mathrm{~m}$ and $2 \mathrm{~m}$; respectively and the space between trees in a plot was $2 \mathrm{~m}$. After planting, the sites were protected from grazing and human interferences. Plantation plots were neither irrigated nor fertilized. Survival rate, plant height (from ground level to the tip of the plant), diameter at breast height (DBH) and root collar diameter (RCD) were recorded every three months from June 2016 - June, 2019.

\section{Data collection}

In order to fit the given objectives, data were collected on growth and adaptation parameters such as Plant height, root collar diameter, diameter at breast height and survival rate for the three years at interval of three months. Root collar diameter were collected only up to the tree reaches 1.3 meters in height and diameter at breast height were collected after tree reaches $1.3 \mathrm{~m}$ whereas plant height and survival rate were up to the end of the period of the activity. Height growth was determined by using measuring tape and root collar diameter and diameter at breast height by digital caliper.

\section{Data analysis}

Analysis of variance was computed using Genstat software ( $18^{\text {th }}$ edition) package to test the significant difference among tree species. Least significant different (LSD) test was employed to separate statistically different means using the software package at 0.05 level of probability.

\section{Resuts and Discussion}

\section{Survival rate}

Among tree species, differences were highly significant $(\mathrm{p}<0.05)$ for survival rate as well (Table 2). After three years of establishment, Moringa olifera demonstrate the highest survival rate at experimental site. This can be attributed to the moisture stress experienced, the growth, survival and distribution of forest trees. Yitebitu [7] also reported that Moringa species are quite drought resistant species which is similar to the observation of the present study. Azadarichta indica, Sesbania sesban, Leuceana leucocephala demonstrated the good survival rate at Erer Dodota condition. Hence, it can be inferred that the condition of Harari matched well with the environment requirement of these species. Gravilea robusta on the other hand, showed lowest survival rate at the study area. The long dry season, which extended from seven to nine months in the study area, clearly explains the low survival of the Gravilea robusta seedlings during the experimental period. In the present study, the mortality was subjectively attributable to abiotic factors such as drought and moisture stress during the initial growth from October to June at the study area. On the other hand, Moringa oliefera, Azadarichta indica, Sesbania sesban and Leuceana leucocephala were found to be highly resistance to moisture stress in the study area. Highly significant variations was among the tree species in survival rate $(\mathrm{p}<0.05)$ was recorded at all three years of age after transplanting.

Table 2: Mean survival rate (\%) of agroforestry tree species planted in Erer Dodota; Harari Region over three years (2016/17 - 2018/19).

\begin{tabular}{|c|c|c|c|}
\hline \multirow{2}{*}{ Tree Species } & \multicolumn{3}{|c|}{ Stages Age of Seedling after Transplanting } \\
\hline & Year $(2016 / 17)$ & Year $(2017 / 18)$ & Year $(2018 / 19)$ \\
\hline Sesbania sesban & $85.67^{\mathrm{a}}$ & $81.00^{\mathrm{a}}$ & $72.33^{\mathrm{a}}$ \\
\hline Azadarichta indica & $86.67^{\mathrm{a}}$ & $86.33^{\mathrm{a}}$ & $79.33^{\mathrm{a}}$ \\
\hline Leuceana leucocephala & $88.33_{a}$ & $78.33^{a}$ & $72.00^{\mathrm{a}}$ \\
\hline Moringa oliefera & $92.67^{\mathrm{a}}$ & $89.00^{\mathrm{a}}$ & $81.33^{a}$ \\
\hline Gravilea robusta & $64.00^{\mathrm{b}}$ & $41.33^{\mathrm{b}}$ & $34.33^{\mathrm{b}}$ \\
\hline $\operatorname{LSD}(0.05)$ & 9.97 & 12.8 & 11.09 \\
\hline
\end{tabular}




\section{International Journal of Environmental Sciences \& Natural Resources}

\begin{tabular}{|c|c|c|c|}
\hline CV $(\%)$ & 6.3 & 9 & 8.7 \\
\hline Mean & 83.5 & 75.2 & 67.9 \\
\hline P value & $<.001$ & $<.001$ & $<.001$ \\
\hline
\end{tabular}

N.B. Means in columns with the same letters are not significantly difference using LSD.

$\mathrm{CV}=$ Coefficient of Variation, LSD= Least Significant Difference.

\section{Height growth}

Analysis of variance revealed that variations in height among tree species were highly significant $(\mathrm{p}<0.05)$ after three years of age at the study area. Height growth trend (Table 3) showed that Azadarichta indica and Moringa oliefera were the tallest trees, followed by Sesbania sesban, Leuceana leucocephala but Gravilea robusta showed the shortest tree at the study area. Result on growth performance also showed that Azadarichta indica and Moringa oliefera were higher than the other species at the study area. Sesbania sesban and Leuceana leucocephala also showed good growth performance at both study area. Similarly, Raebild et al. [8] also stated that apart from indicating productivity, height may also be seen as a measure of the adaptability of trees to the environment as tall trees usually being better adapted to the site than short trees [9]. Moringa species could also play a great importance in the rehabilitation process especially during periods of drought or in areas where nutrient resources are not available. Several similar studies also showed that fast growth of seedling is an important indicator in terms of determining the situation of growth response especially in the first growing period and it is commonly assumed that the early fast growth rates of tropical trees reflect productivity status of the trees [10].

Table 3: The mean of Plant height, survival rate, diameter at breast height and root collar diameter of multipurpose tree species for three years (2016/17 - 2018/19) at Erer Dodota.

\begin{tabular}{|c|c|c|c|c|}
\hline Tree Species & Survival Rate (\%) & Ht (m) & $\mathrm{RCD}(\mathrm{cm})$ & $\mathrm{DBH}(\mathrm{cm})$ \\
\hline Sesbania sesban & $80.00^{\mathrm{b}}$ & $3.167^{\mathrm{b}}$ & $7.450^{\mathrm{b}}$ & $4.533^{\mathrm{a}}$ \\
\hline Azadarichta indica & $84.33^{\mathrm{ab}}$ & $3.917^{\mathrm{a}}$ & $10.150^{\mathrm{a}}$ & $4.883^{\mathrm{a}}$ \\
\hline Leuceana leucocephala & $79.67^{\mathrm{b}}$ & $3.217^{\mathrm{b}}$ & $7.883^{\mathrm{b}}$ & $4.267^{\mathrm{a}}$ \\
\hline Moringa oliefera & $87.67^{\mathrm{a}}$ & $3.500^{\mathrm{ab}}$ & $9.667^{\mathrm{a}}$ & $4.400^{\mathrm{a}}$ \\
\hline Gravilea robusta & $46.33^{c}$ & $1.490^{\mathrm{c}}$ & $4.617^{c}$ & $3.083^{b}$ \\
\hline $\operatorname{LSD}(0.05)$ & 7.078 & 0.5283 & 1.052 & 0.885 \\
\hline CV (\%) & 5 & 9.2 & 7 & 11.1 \\
\hline Mean & 75.6 & 3.058 & 7.95 & 4.23 \\
\hline$P$ value & $<.001$ & $<.001$ & $<.001$ & 0.013 \\
\hline
\end{tabular}

Means with the same letters are not significantly different using LSD.

$\mathrm{CV}=$ Coefficient of Variation; LSD $=$ Least Significant Difference.

\section{Diameter growth}

As depicted in Table 3, there is significant variation among tree species in diameter growth at the study area. Diameter growth trend shows that the highest root collar diameter was recorded for Azadarichta indica followed by Moringa oliefera, Sesbania sesban and Leuceana leucocephala but the lowest root collar diameter was recorded for Gravilea robusta at the study area condition. Growth in DBH also a significant $(\mathrm{p}<0.05)$ variation for the five multipurpose tree species. The difference in DBH $(1.3 \mathrm{~m})$ above the ground of tree species Azadarichta indica, Moringa oliefera, Sesbania sesban and Leuceana leucocephala showed highest diameter at breast height (DBH) within three years data records at Erer Dodota environment condition. On the other hand Gravilea robusta showed the lowest DBH [11-13] (Figure 3).

\section{Conclusion and Recommendation}

The results indicated that there were significant effect among tree species for plant height, survival rate, root collar diameter and diameter at breast height. The survival rate of Moringa oliefera was the highest followed by Azadarichta indica, Sesbania sesban and Leuceana leucocephala. While Gravilea robusta showed poor survival rate at the study area. Poor survival rate and growth performance might be attributed to the condition and termite problems of the study area. Moringa oliefera, Sesbania sesban, Leuceana leucocephala and Azadarichta indica were the species attained the highest mean heights, while Gravilea robusta had the lowest values. The comparisons between the height and diameter growth average of the species showed that Azadarichta indica had the highest mean height followed by Moringa oliefera, 
Leuceana leucocephala and Sesbania sesban. Generally, results on growth performance showed that Azadarichta indica, Sesbania sesban, Moringa oliefera and Leuceana leucocephala had better performance than Gravilea robustaat the study area. Accordingly, those tree species which had better performance were recommended for further demonstration and evaluation in the study area and similar agro ecologies. Therefore; planting of these better performing tree species and increase their promotion as agroforestry practices were recommended for soil conservation, shading, forage, fuel wood and in general multifunction purposes in the area.

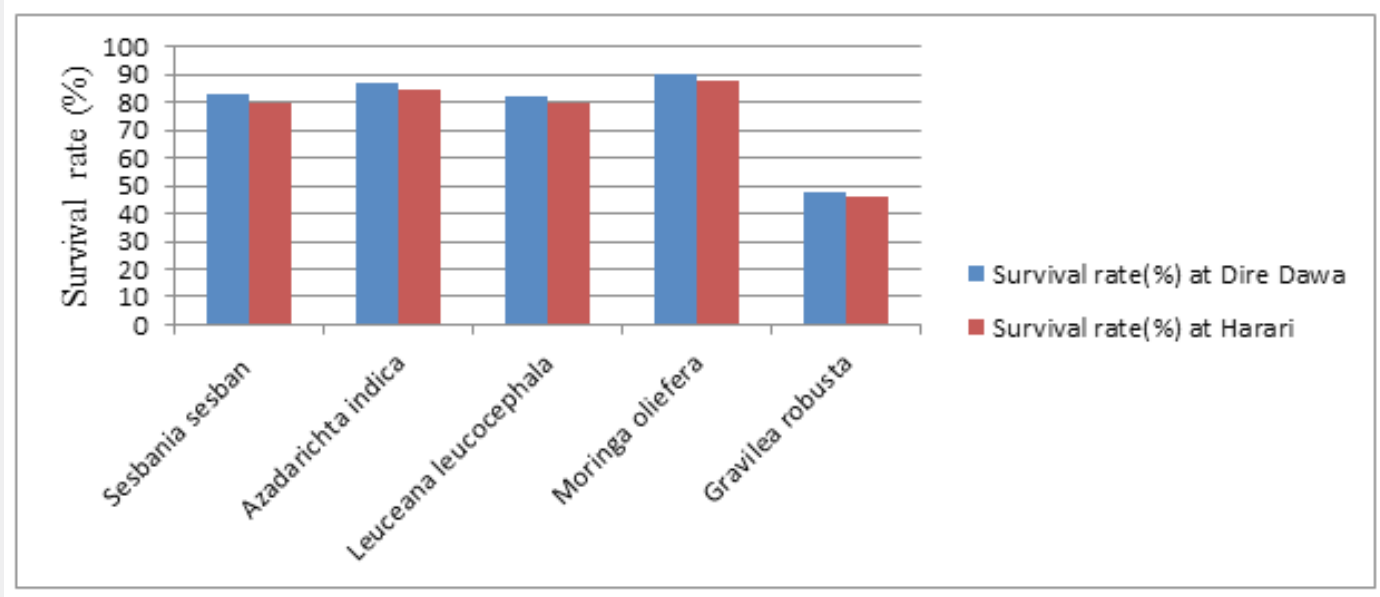

Figure 3: Means of survival rate (\%) of Gravilea robusta, Azadarichta indica, Leuceana leucocephala, Moringa oliefera and Sesbania sesban through sequential periods from June 2016 to June 2019 at Erer Dodota.

\section{Acknowledgement}

We would like to thanks Oromia Agricultural Research Institute for financial support and Fadis Agricultural Research Center for provision of the necessary facilities for research work. We also express our sincere appreciation to the Central Ethiopian Environment and Forestry Research Center for provision of tree seeds for the study.

\section{References}

1. Yadessa A, Bekere D, Bekele T (2000) Growth performance of different multipurpose tree and shrubs species at Bako, Western Oromia. In: Proceedings of the Fifth Conference of the Ethiopian Society of Soil Science. Addis Ababa, Ethiopia, 30-31 March 2000, Ethiopian Society of Soil Science. Addis Ababa, Ethiopia, pp. 177-186.

2. Mihretu M, Gezahegn A, Belachew (2004) Early survival and height performance of some Australian species in field trials at Didessa, western. Ethiopian Journal of Natural Resources (EJNR) 6(2): 253-263.

3. Brockerhoff EG, Jactel H, Parrotta JA, Quine CP, Sayer JJ (2008) Plantation forests and biodiversity: oxymoron or opportunity? Biodiversity Conservation 17: 925-951.

4. Alemu B, Mamo T, Zewdie A, Ahmed E (2000) Promising multipurpose tree species and their response to land form on highland vertisols at Chefe Donsa, central highland of Ethiopia. pp. 145-155.

5. Berhe K, Conchedda G, Jabbar M (2001) Areas suitable for five leguminous trees and shrubs in Ethiopia: A digital data based analysis. Ethiopian Journal of Natural Resources (EJNR) 3(1): 77-97.

6. Yakob G, Asfaw Z, Zewdie S (2014) Wood production and management of woody species in homegardens agroforestry: The case of small holder farmers in Gimbo district, South West Ethiopia. International Journal of Natural Sciences Research 2(10): 165-175.

7. Moges Y (2004) Recommended Agroforestry/Multipurpose Trees for Borana Lowlands/Midlands and their Production Techniques. Subreport, No.4.

8. Raebild A, Graudal L, Rehman SK (2003) Evaluation of a provenance trial with Acacia albida, A. Senegal and A. tortilis at Dagar Kotli, Pakistan. Trial no. 21 in the arid zone series. Results and Documentation No. 26.

9. Cossalter C (1987) Introduction of Australian acacias into dry, tropical West Africa. Forest Ecology and Management 16(1-4): 367-389.

10. Baris H, Ertenki M (2010) Growth models in investigating oriental beech (Fagus orientalis Lipsky). Romanian Biotechnological Letters 16: 5850-5857.

11. Casper BB, Jackson RB (1997) Plant competition underground. Annual Review of Ecology and Systematic 28: 545-570.

12. Teketel D (2001) Deforestation, wood famine, and environmental degradation in Ethiopia's highland Ecosystems: urgent need for action. Northeast African Studies 8(1): 53-76.

13. Kozlowski TT, Kramer PJ, Pallardy SG (1991) The physiological ecology of woody plants. Academic Press, Toronto. p. 657. 
Your next submission with Juniper Publishers will reach you the below assets

- Quality Editorial service

- Swift Peer Review

- Reprints availability

- E-prints Service

- Manuscript Podcast for convenient understanding

- Global attainment for your research

- Manuscript accessibility in different formats ( Pdf, E-pub, Full Text, Audio)

- Unceasing customer service

Track the below URL for one-step submission https://juniperpublishers.com/online-submission.php 